\title{
Analysis of Parameters and Processes of Latvian Seafarers' Pool
}

\author{
R. Gailitis \\ Latvian Maritime Administration, Riga, Latvia
}

\begin{abstract}
Maritime industry plays a key role for economy of the European Union. During recent years increasing attention is paid to the education and training of seafarers as the seafarers and their knowledge are essential to sustainable development of the maritime cluster, as indicated in the maritime strategy of European Union. However, for successful implementation of the strategy understanding of current trends in the pool of seafarers is prerequisite. Therefore the aim of this article is to analyze parameters and processes of Latvian seafarer's pool, based on information from database of Maritime Administration of Latvia Seamen Registry. The structure of database and data collected there gives possibility to analyze the processes taking into account the global changes in shipping and their impact to the structure of the pool. Such analysis in combination with the calculations of economical value of seafarer's pool creates the framework on which the decisions about the implementation of maritime strategy in Latvia can be taken.
\end{abstract}

\section{INTRODUCTION}

Nowadays wide attention within maritime society is paid to the shortage of seafarers. It is subject for lot of discussions going on in maritime industry. The worldwide supply of seafarers in 2010 was estimated to be 624,000 officers and 747,000 ratings, while the current estimate of worldwide demand for seafarers (in 2010) is 637,000 officers and 747,000 ratings (BIMCO/ ISF 2010). As one of the response to shortage of seafarers the International Maritime Organization in 2008 launched campaign "Go to sea" to attract entrants to the shipping industry (IMO 2008).

However it takes time for such a campaign to give results. And it is difficult to assess the results if there is no available information about changes in number of entrants. The Task Force on Maritime Employment and Competitiveness in their report underlined the need for reliable data to assess the scope and scale of the problems regarding shortage of seafarers (EC, 2011a).

European Union (EU) policy papers also underlines the importance of shortage of the seafarers as the seafarers and their knowledge, skills and competences are perceived as important resource for sustainable European maritime cluster development. European Maritime Safety agency is going to create unified database collecting the information regarding the issued certificates of competency by EU member states. While this data system is not launched it is difficult to predict what will be the possibilities of such a system. The problem with the data is clearly stated in Study on EU seafarers' employment - It is clear that detailed data on maritime employment is scarce, sometimes outdated and often not reliable. Moreover, the great differences from a country to another in data collect and presentation of results prevent all serious analysis on employment structure and evolution (EC, 2011b).

Therefore this article will show the experience of Seamen Registry of Latvian Maritime administration in analysis of parameters and processes of Latvian Seafarers pool.

\section{DATABASE OF LATVIAN SEAMEN REGISTRY}

The basis for any analysis is information. To analyse processes and parameters of pool of seafarers Seamen Registry of Latvian Maritime Administration uses information from database of Latvian Seamen Registry. The main aim for database of Latvian Seamen Registry is to serve for seafarers' certification purposes according national and STCW requirements. The database contains 
information not only about the issued certificates but also about the employment, education, training and seamen discharge book. See table 1.

Table 1. Data areas, sources and main information fields of database of Latvian Seamen Registry

\begin{tabular}{|c|c|c|}
\hline Data area & Main data provider & Main fields \\
\hline Personal data & Seafarer & $\begin{array}{l}\text { Birth date, place of living, } \\
\text { nationality }\end{array}$ \\
\hline $\begin{array}{l}\text { Certificates of } \\
\text { competence } \\
\text { and other } \\
\text { qualification } \\
\text { documents }\end{array}$ & $\begin{array}{l}\text { f Issuing organization, } \\
\text { seafarer }\end{array}$ & $\begin{array}{l}\text { STCW reference, } \\
\text { validity of } \\
\text { endorsement }\end{array}$ \\
\hline Education & Education institution & $\begin{array}{l}\text { Name of programme, } \\
\text { qualification, STCW } \\
\text { reference, graduation year }\end{array}$ \\
\hline Training & Training organization & $\begin{array}{l}\text { Training course, STCW } \\
\text { reference, validity of } \\
\text { course, course date }\end{array}$ \\
\hline Employment & $\begin{array}{l}\text { National crewing } \\
\text { agencies }\end{array}$ & $\begin{array}{l}\text { Ship name, flag, } \\
\text { employment, period, } \\
\text { capacity on board }\end{array}$ \\
\hline
\end{tabular}

The database is based on the seafarer as data unit and related records of individual person. Each person in database has his own information blocks, where records regarding his education, training, employment certificates can be found. Main data providers are the Seamen registry, seafarers, companies and training centres.

\section{NUMBER OF SEAFARERS IN LATVIA AND THEIR AGE}

The number of seafarers in Latvia is calculated every year with reference date 1st January. The base for the number of seafarers is taken the number of valid documents of competence or qualifications such as certificates of competency or certificates of qualification. The validity period of endorsement or qualification document is five years, therefore it is assumed if the endorsement is not revalidated seafarers has been left the pool of active seafarers. The data about employment cannot provide fully complete picture of active number of Latvian seafarers as approximately $10 \%$ of seafarers are employed directly or through foreign crewing companies, which are not obliged to provide data about employment to Latvian Seamen registry. Also part of seafarers doesn't sail regularly, therefore it is difficult to assess employment data accuracy level and they are used as secondary indicator. In calculations the last valid certificates is taken as indicator showing the qualification and its level as person can have two or more valid certificates on hand at the same time.

The active or employed seafarer is person who holds a valid certificate and therefore can be employed on board. Therefore the published figures about the number of seafarers reflect the number of persons with valid certificates even they are not employed on board in particular year. The size on structure of active seafarers' pool in Latvian on is given in table 2.

Table 2. Size and structure of seafarers' pool (2013)

\begin{tabular}{lc}
\hline Total number of seafarers & 12,970 \\
1) Merchant fleet seafarers: & 11,960 \\
1.1) Deck department & 5650 \\
Officers & 2500 \\
Ratings & 3150 \\
1.2) Engine department: & 4890 \\
Officers & 3040 \\
Ratings & 1850 \\
1.3) Catering department (cooks, stewards) & 1400 \\
2) Inland fleet seafarers \& personell of fishing vessels 1010 \\
\hline
\end{tabular}

92\% of seafarers are merchant fleet seafarers. From them $47 \%$ are classified as deck department seafarers, $41 \%$ are classified as engine department seafarers, but $12 \%$ are classified as catering departments' seafarers. As the shortage of seafarers is referenced to shortage of officers detailed structure of officers is shown in table 3.

Table 3. Structure of officers according the department

Deck officers from officers $45 \%$

Officer in charge of navigational watch

(from deck officers)

Master on ships of 3000 GT or more

(from deck officers)

Chief officer on ships of $3000 \mathrm{GT}$ or

more (from deck officers)

Engine officers from officers

Officers in charge of an engineering watch

on ships with $750 \mathrm{~kW}$ propulsion power or

more (from engine officers)

Chief Engineer Officers on ships with $3000 \mathrm{~kW}$ A-III/2 33\%

propulsion power or more (from engine officers)

Second Engineer Officers on-ships-with 3000kw A-III/2 21\% propulsion power or more(from engine officers)

Non STCW officers (from engine officers)

$19 \%$

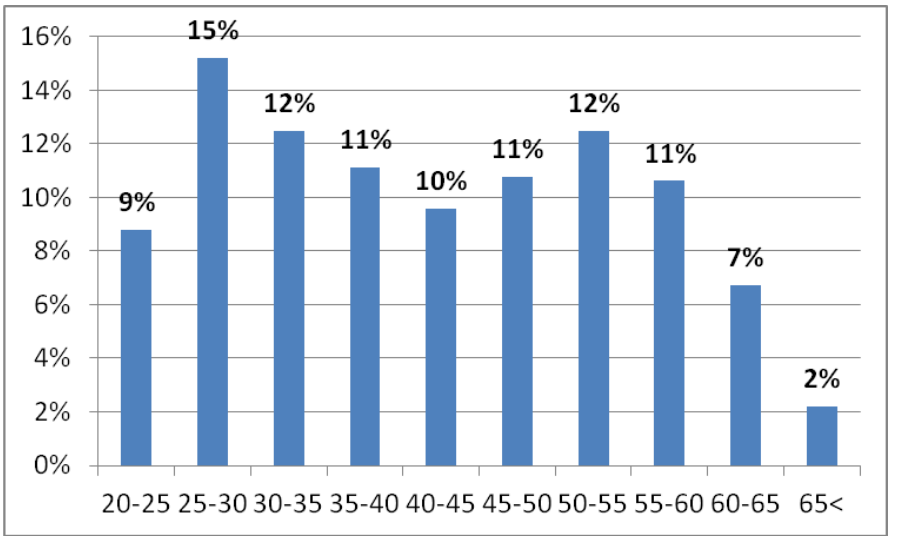

Figure 1. Age structure of merchant fleet seafarers

Share of deck officers is $45 \%$ from all persons with valid officers' certificates. Main part of all officers both in engine (54\%) and deck department $(63 \%)$ has management level certificates which 
allow them to sail on ships with $3000 \mathrm{GT} / 3000 \mathrm{~kW}$ propulsion power or more. The number of seafarers doesn't provide information about how much seafarers are close to retirement age or how much seafarer started their career recently. To have overall picture the figure 1 shows the average age structure of merchant fleet seafarers.

Analysing the average age structure it can be seen that proportion of merchant fleet increases till age of 30 years and then decreases. Active number of seafarers decreases starting from age 60 . It can be assumed that active seafarers are in age range from 20 -65 years (approximately 96\% of seafarers are within this age range). Also it is clear that seafarers over 65 years old will retire in closest years. Parallel the seafarers with different qualifications from different departments can be analysed. The table 4 shows how much seafarer from all seafarers with particular qualification can be found in age group.

Table 4. Age groups of seafarers in deck and engine department

\begin{tabular}{|c|c|c|c|c|c|}
\hline Age group & $20-30$ & $30-40$ & $40-50$ & $50-60$ & $60<$ \\
\hline $\begin{array}{l}\text { Masters on } \\
\text { ships > } 3000 \mathrm{GT}\end{array}$ & $1 \%$ & $21 \%$ & $21 \%$ & $42 \%$ & $15 \%$ \\
\hline $\begin{array}{l}\text { Chief officers on } \\
\text { ships }>3000 \mathrm{GT}\end{array}$ & $18 \%$ & $45 \%$ & $17 \%$ & $16 \%$ & $4 \%$ \\
\hline $\begin{array}{l}\text { Watch officers on } \\
\text { ships > 500 GT }\end{array}$ & $53 \%$ & $26 \%$ & $12 \%$ & $7 \%$ & $2 \%$ \\
\hline Deck ratings & $35 \%$ & $22 \%$ & $18 \%$ & $18 \%$ & $6 \%$ \\
\hline $\begin{array}{l}\text { Chief engineers on } \\
\text { ships }>3000 \mathrm{~kW}\end{array}$ & $0 \%$ & $19 \%$ & $29 \%$ & $35 \%$ & $17 \%$ \\
\hline $\begin{array}{l}\text { Second engineers } \\
\text { on ships > } 3000 \mathrm{~kW}\end{array}$ & $9 \%$ & $36 \%$ & $29 \%$ & $20 \%$ & $6 \%$ \\
\hline $\begin{array}{l}\text { Watch engineers } \\
\text { on Ships }>750 \mathrm{~kW}\end{array}$ & $40 \%$ & $35 \%$ & $17 \%$ & $9 \%$ & $1 \%$ \\
\hline Engine ratings & $27 \%$ & $18 \%$ & $20 \%$ & $25 \%$ & $10 \%$ \\
\hline
\end{tabular}

Approximately half of the ratings both in engine and deck department are in age till 40 years. Largest group of watch officers and engine officers is in age till 30 years. The largest groups of chief engineers and captains are in age from 50 till 60 years.

\section{INFLOW OF SEAFARERS}

However these parameters reflect only how much active seafarer are in particular age group. To understand the inflow process the overall analyses of persons who have received document of competence issued by Latvian Seamen Registry is applied in table 5. The time period is chosen $2005-2012$ to have view on inflow changes in last year's.

The number of persons reflects how much persons received their first document of competence at given year. As it can be seen approximately $82 \%$ of all persons were in age till 30. Also half of the persons received the document related to deck department (rating or watch officer). It can be also concluded that inflow has been decreased in last year's. To understand what will be the impact on smaller inflow to the total number the whole pool both active and ex seafarers should be considered and outflow of the pool due to the age and other reasons.

Table 5. Data of inflow of merchant fleet seafarers (20052013)

\begin{tabular}{ccccc}
\hline $\begin{array}{c}\text { Year Number In age } \\
\text { of } \\
\text { persons }\end{array}$ & $\begin{array}{c}\text { till 30 } \\
\text { Deck } \\
\text { department }\end{array}$ & $\begin{array}{c}\text { Department } \\
\text { Engine } \\
\text { department }\end{array}$ & $\begin{array}{l}\text { Catering } \\
\text { department }\end{array}$ \\
\hline 2005540 & $83 \%$ & $56 \%$ & $35 \%$ & $9 \%$ \\
2006420 & $83 \%$ & $43 \%$ & $34 \%$ & $23 \%$ \\
2007340 & $86 \%$ & $55 \%$ & $29 \%$ & $15 \%$ \\
2008320 & $81 \%$ & $46 \%$ & $25 \%$ & $30 \%$ \\
2009520 & $79 \%$ & $43 \%$ & $26 \%$ & $30 \%$ \\
2010460 & $77 \%$ & $49 \%$ & $28 \%$ & $23 \%$ \\
2011400 & $85 \%$ & $50 \%$ & $31 \%$ & $18 \%$ \\
2012390 & $85 \%$ & $52 \%$ & $20 \%$ & $28 \%$ \\
\hline
\end{tabular}

\section{OUTFLOW OF SEAFARERS}

Outflow of the pool is linked with two factors. One factor is retirement when seafarers reach the age of 65 as it can be concluded from age structure of active seafarers. (Only two percent of active seafarers are in age over 65.) Other factor is demand from maritime companies ashore which are willing to employ persons with seagoing knowledge and experience and employment possibilities in other industries which can utilise the skills of seafarers in the same time providing competitive or better employment conditions.

Determination of persons who will retire in next five years is quite simple. From active seafarers 1050 seafarers are in age over 60 years. From them $15 \%$ are persons with certificate "Masters on ships > 3000 GT", 16\% are persons with certificate "Chief engineers on ships $>3000 \mathrm{~kW}$ " but $36 \%$ are persons with deck and engine rating certificates. Therefore it can be assumed that outflow rate due to the age at this size and composition of pool is approximately 200 persons per year.

It is more difficult to determine the demand from maritime companies ashore or to quantify pulling factors from other industries. Therefore pool of all persons which have ever received document of competence and are in age till 65 should be considered. According the data from database there are 19150 persons who have received a document of competence to serve on merchant vessels and now are in age range from 20 till 65 years. Therefore as ex seafarers in total can be considered 7700 persons as number of active seafarers is 11450 within age range from 20 - 65 years. The composition of ex seafarers is given in table 6 .

Main part of ex seafarers is deck and engine ratings. Approximately $28 \%$ or 2120 persons from ex seafarer had competence document as officer. 
Therefore it can be assumed that approximately such demand exist ashore for persons with officers qualification, educational background, experience and skills. However database doesn't allow following to their employment ashore to see if they are still working within maritime industry or they are working in other industries. Other factor which can be derived from database is activity level of particular qualification (see table 7). This parameter shows how much persons from all persons with such a qualification are still active.

Table 6. Composition of ex seafarers

\begin{tabular}{ll}
\hline 1. Deck department & $53 \%$ \\
1.1. Deck officers & $12 \%$ \\
1.2. Deck ratings & $42 \%$ \\
2. Engine department & $38 \%$ \\
2.1.Engine officers & $16 \%$ \\
2.2. Engine ratings & $22 \%$ \\
3. Catering department & $9 \%$ \\
\hline
\end{tabular}

Table 7: Activity level of particular qualification seafarers

\begin{tabular}{ll}
\hline Masters on ships > 3000 GT & $80 \%$ \\
Chief officers on ships > 3000 GT & $79 \%$ \\
Watch officers on ships > 500 GT & $70 \%$ \\
Deck ratings & $49 \%$ \\
Chief engineers on ships > 3000 kW & $84 \%$ \\
Second engineers on ships > 3000 kW & $74 \%$ \\
Watch engineers on Ships > 750 kW & $57 \%$ \\
Engine ratings & $52 \%$ \\
\hline
\end{tabular}

The highest activity is for management level officers while lowest for ratings both in deck and engine departments. These data shows that demand from maritime companies ashore to employ persons with officers' maritime knowledge and experience is fully covered and companies have possibility to find right person for employment ashore.

Table 8. Outflow at particular age group (2005 - 2010)

\begin{tabular}{ccccc}
\hline Age group Deck officers Engine officers & All officers & Ratings \\
\hline $20-25$ & $26 \%$ & $27 \%$ & $27 \%$ & $35 \%$ \\
$25-30$ & $23 \%$ & $20 \%$ & $21 \%$ & $37 \%$ \\
$30-35$ & $20 \%$ & $15 \%$ & $17 \%$ & $33 \%$ \\
$35-40$ & $19 \%$ & $14 \%$ & $16 \%$ & $30 \%$ \\
$40-45$ & $21 \%$ & $22 \%$ & $22 \%$ & $26 \%$ \\
$45-50$ & $19 \%$ & $22 \%$ & $21 \%$ & $28 \%$ \\
$50-55$ & $26 \%$ & $21 \%$ & $23 \%$ & $33 \%$ \\
$55-60$ & $45 \%$ & $48 \%$ & $47 \%$ & $61 \%$ \\
$60-65$ & $62 \%$ & $65 \%$ & $65 \%$ & $84 \%$ \\
$65-70$ & $88 \%$ & $84 \%$ & $85 \%$ & $100 \%$ \\
Average & $25 \%$ & $24 \%$ & $24 \%$ & $35 \%$ \\
till 60 & & & &
\end{tabular}

From previous analysis it can be determined that main inflow is till age of 30 years and the outflow due to the retirement is after 65 years. Also the size of demand for ex officers is determined. However these data is not sufficient to determine what is outflow at particular age group. Therefore the data about employment of Latvian seafarers was compared in 2005 and 2010. The sample of seafarers employed on different types of ships in 2005 is 10980 seafarers. Comparing with data about employment in 2010 the size of sample is 10050 . It gives possibility by comparing the data about the seafarers who are employed in both years calculate how much of them have probably left the pool (see table 8). As it is said earlier valid certificate of competence is not always linked to employment on board therefore the data of employment is used in this case.

The data shows that persons till age of 30 have higher probability to leave the pool than persons in age range 30-55 years. Starting from 55 years persons have high probability to leave the pool, which can be linked to the coming retirement age and motivation to go to work ashore. Those data again shows the tendency that ratings are more elastic to leave the employment at sea than officers as outflow rates for ratings are higher than for officers. Also it can be assumed that higher rates in age group from 20 - 30 means that for other industries or maritime companies is much easier to attract persons at that age. For all seafarers including the catering department (which is no showed on table 8) the average outflow rate is $32 \%$ which means that additionally to the retirement on average one third of active seafarers leaved the pool due to the demand factors ashore. However those figures in table 8 should be considered with care as the data in table reflects maximum outflow values.

\section{CONCLUSIONS}

From showed analysis it can be concluded that for present composition of Latvian seafarers' pool the inflow is sufficient to cover the retirement outflow. The other important factor which influences the number of available or active seafarers is outflow due to the demand from maritime companies ashore or other industries which can offer the competitive employment conditions. The present analysis doesn't offer possibility to determine average value for outflow ashore which could give possibility to determine if inflow is sufficient to cover the demand from ashore.

However it is clear that in determination of shortage of seafarers demand from ashore also should be considered and included.

\section{REFERENCES}

BIMCO/ISF 2010. Highlights from the Manpower 2010 Update.

European Commission 2011 a. Report of the Task Force on Maritime Employment and Competitiveness and Policy.

European Commission. Directorate-General for mobility and transport 2011 b. STUDY ON EU SEAFARERS EMPLOYMENT. FINAL REPORT. 